\title{
Presentation of a Rare Case: Acute Kidney Failure Developed Following Complete Urinary Bladder Herniation and Management of Postoperative Voiding Dysfunction
}

\section{Nadir Bir Vaka Takdimi: Komplet Mesane Herniasyonu Sonrası Gelişen Akut Böbrek Yetmezliği ve Postoperatif Miksiyon Bozukluğunun Yönetimi}

\author{
Mecit Celik (D, Muhammed Emin Polat (D, Caglar Sarioglu (D, Bugra Bilge Keseroglu (D
}

Department of Urology, University of Health Sciences, Ankara City Hospital, Ankara, Turkey

Cite as: Celik M, Polat ME, Sarioglu C, Keseroglu BB. Presentation of a rare case: Acute kidney failure developed following complete urinary bladder herniation and management of postoperative voiding dysfunction. Grand J Urol 2021;1(3):138-141.

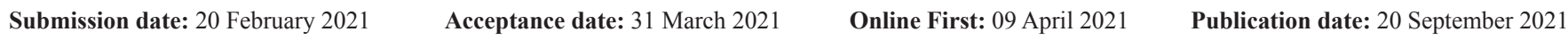

Corresponding Author: Muhammed Emin Polat / Department of Urology, University of Health Sciences, Ankara City Hospital, Ankara, Turkey / emnplt25@gmail.com ORCID ID: 0000-0003-0271-0746

\begin{abstract}
Inguinal bladder herniation is seen in $1 \%-4 \%$ of all inguinal hernia cases; most of them are asymptomatic and come up with swelling in the groin. In symptomatic cases, nonspecific findings such as lower urinary tract symptoms or pain due to strangulation of the hernia sac are seen. Two-stage micturition (manual pressure to the scrotum to empty residual urine) is a pathognomonic sign for the advanced case. Vesicoureteral reflux (VUR), bilateral hydronephrosis, urinary tract infection, acute kidney failure and bladder wall necrosis are complications that may be seen if the problem is not appropriately managed. Preoperative diagnosis rates are low $(<7 \%)$ and $16 \%$ of the cases are diagnosed in the postoperative period, and most cases are detected intraoperatively. Radiologic examination performed for other indications such as non-contrast abdominal computed tomography (CT) may diagnose the bladder herniation. CT, cystography and ultrasonography are the techniques that can be used in the diagnosis and differential diagnosis. Intraoperatively, reduction of the herniated bladder with herniorrhaphy is a routine procedure. Partial cystectomy has to be made in case of bladder wall necrosis, presence of a tumor in the herniated bladder and narrow bladder neck which don't allow reduction.

In this case report, our aim is to explain the management of left inguinoscrotal complete bladder herniation and postoperative voiding problem.
\end{abstract}

Keywords: bladder, herniaton, kidney, kidney failure

Öz

Kasık mesane herniasyonu tüm kasık fitığı vakalarının\% 1-\% 4'ünde görülür. Çoğu semptomatik değildir ve kasıkta şişlik ile ortaya çıkar. Semptomları olanlarda; alt üriner sistem semptomları veya fitık kesesinin boğulmasına bağlı ağnı gibi spesifik olmayan bulgular görülür. İleri evre herniasyonlarda iki fazlı işeme (artık idrarı boşaltmak için herniye bölgeye el ile bastırrma) bulgusu patognomonik bir işarettir. Vezikoüreteral reflü (VUR), bilateral hidronefroz, idrar yolu infeksiyonu, akut böbrek yetmezliği ve herniye mesane duvarı nekrozu, vaka uygun şekilde yönetilmezse görülebilecek komplikasyonlardır. Operasyon öncesi tanı oranları $(<\% 7)$ düşüktür ve vakaların \%16'sı postoperatif dönemde tanı almakta, çoğu vaka ise intraoperatif tespit edilmektedir. Kontrastlı olmayan abdominal bilgisayarlı tomografi (BT) gibi başka nedenlerle yapılan radyolojik incelemelerde mesane herniasyonunu teşhis edebilir. Tanı ve ayırıcı tanıda bilgisayarlı tomografi, sistografi ve ultrasonografi kullanılabilecek tekniklerdir. Operasyon sırasından herniye mesanenin redüksiyonu ve defektin onarımı yeterli olup, herniye mesanenin nekrozu, içinde tümör varlı̆g 1 veya redüksiyona izin vermeyen dar mesane boyun durumlarında parsiyel sistektomi yapılmalıdır.

Bu olgu sunumunda amacımız sol inguinoskrotal tam mesane herniasyonunun ve postoperatif dönemde gelişen işeme sorununun yönetimini açıklamaktır.

Anahtar kelimeler: mesane, herniasyon, böbrek, böbrek yetmezliği 


\section{Introduction}

Inguinal bladder hernia was described first in 1951 by Levine $[1,2]$. Although bladder herniation is seen in $1 \%-4 \%$ of cases with inguinal herniation, massive herniation of the bladder is very rare. Incidence of bladder herniation increases in obese people, males, and individuals aged $>50$ years $[3,4]$.

Most of the patients with bladder hernias are asymptomatic and diagnosed during inguinal hernia repair [5]. Less than 7\% of patients are diagnosed preoperatively, and $16 \%$ of them postoperatively because of complications [6].

There are nonspecific urologic symptoms because of urinary retention, such as urgency, frequency, nocturia. Urinary tract infection, bilateral hydronephrosis, renal failure and bladder infarction may be seen if it isn't diagnosed timely and properly [7].

We present the case of a male patient who came to the emergency department with the complaint of scrotal swelling that had been present for one week. He had left inguinoscrotal hernia and the entire bladder of the patient was herniated into the inguinal canal, and also acute kidney failure developed.

\section{Case Presentation}

Fifty-six years old man who had scrotal swelling for seven days came to the emergency department. From his medical history we have learned that he had diabetes mellitus, hypertension and benign prostatic hyperplasia (BPH) and used an oral antidiabetic drug, calcium channel blocker for hypertension and alpha-blocker for BPH. Despite medical therapy used for BPH, he suffered from lower urinary tract symptoms. During his physical examination, bilateral pretibial grade 2 edema was found, and his biochemical analysis revealed higher urea and creatinine levels. His anamnesis revealed two stage micturition (manual pressure to the scrotum to empty residual urine). Nonenhanced computed tomography (CT) was taken by emergency department physicians before the urologic examination to explain postrenal etiology in acute kidney failure. CT scan revealed grade 2-3 bilateral hydronephrosis. Diameters of both ureters increased. A catheter balloon was observed in the bladder. The bladder was herniated into the left inguinal canal, and the ureters opened to the bladder at the level of the inguinal canal. Before the planned operation, cystography was taken (Figure 1).

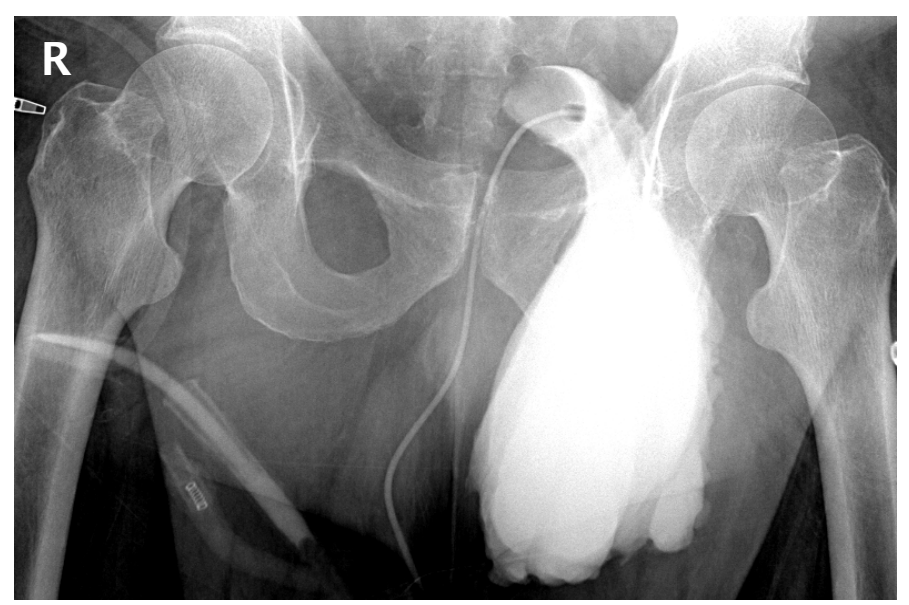

Figure 1. Preoperative cystogram
Intraoperative findings demonstrated a giant direct left inguinoscrotal hernia with total herniation of the bladder into the scrotum. The bladder was reduced into the abdominal cavity without complication followed by herniorrhaphy. A closed suction drain was placed in the scrotum, and removed on the postoperative second day. Antibiotic treatment was started due to fever on the third postoperative day. After ten days of intravenous antibiotic treatment which recommended by infectious disease department, the patient was discharged with a urethral catheter and normal renal function values. The urethral catheter was removed after the control cystogram obtained one week after discharge (Figure 2). Cystogram revealed that the bladder was in its anatomical position. Unfortunately, urodynamics was planned because the patient was unable to urinate after the catheter was removed. In urodynamics, detrusor pressures did not increase despite $500 \mathrm{cc}$ of isotonic fluid instilled during urodynamic examination, and the patient could not urinate (Figure 3). Clean intermittent self-catheterization four times a day and maintenance of daily use of an alpha-blocker was recommended. At the control visit planned three months later, it was determined that the need for clean intermittent catheterization decreased to 2 times a day, and he started to urinate spontaneously.

\section{Discussion}

Herniation of the bladder accounts for approximately $1 \%$ $-4 \%$ of inguinal hernias. After the 5 th decade, the incidence of bladder herniation reaches up to $10 \%$ [2]. The inguinal herniation is often seen in males and into the right inguinal canal $[2$, 7-9]. The conditions that are thought to play role in the pathophysiology of bladder herniation as a risk factors in studies performed to date are as follows: a) aging, b) obesity, c) bladder outlet obstruction, d) decreased bladder tone and weakness in the pelvic muscles $[3,4,10]$. In our case, the patient was over 50 years old, obese and using alpha-blockers due to benign prostatic hyperplasia.

Patients with inguinal bladder herniation are generally asymptomatic, and the majority of patients present with complaints of swelling in the groin $[5,6]$. In the anamnesis, usually accompanying lower urinary tract symptoms are detected. Addi-

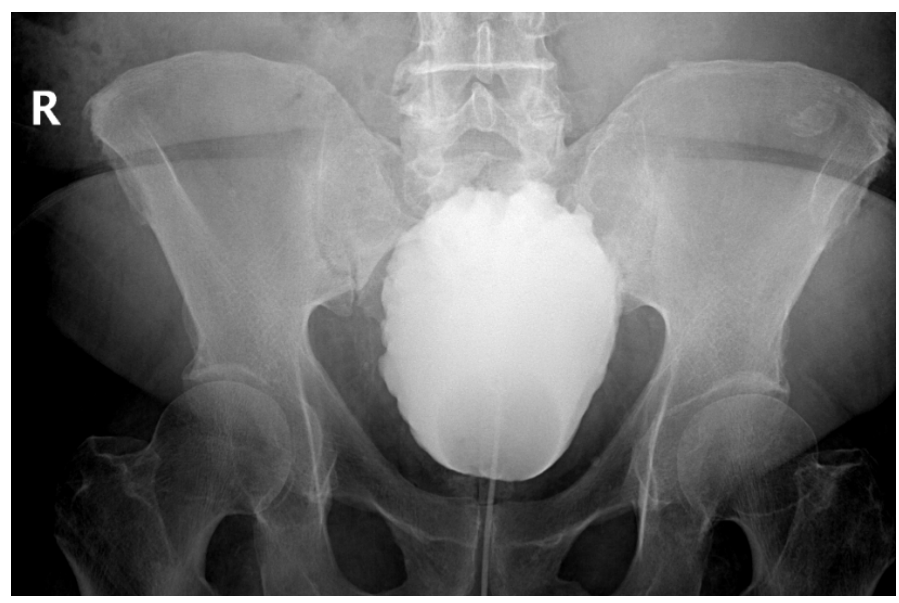

Figure 2. Control cystogram (postoperative 20th day) 


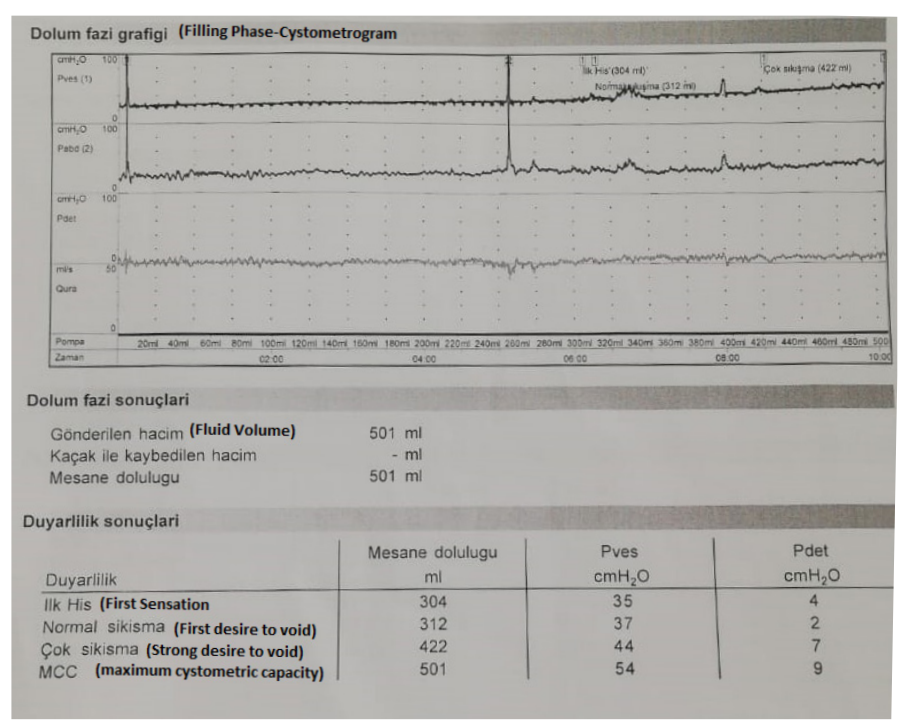

Figure 3. Urodynamic study (postoperative 22nd day)

tionally, pain due to strangulation of hernia, diminish in scrotal size after voiding and two-stage urination are seen in advanced stages $[7,11]$. In our case, the patient applied with the complaint of scrotal swelling that had been present for one week. In the questioning, it was seen that the patient used alpha-blocker due to lower urinary tract symptoms secondary to benign prostatic hyperplasia.

Complications of inguinal bladder herniation include bilateral hydronephrosis with or without acute renal failure, vesicoureteral reflux, sepsis, cystolithiasis, strangulation and bladder wall necrosis $[2,6,7,12,13]$. In our case, there was acute renal failure developed together with bilateral hydronephrosis and, luckily, there was no ischemic appearance in the bladder wall.

Herniation of the bladder into the inguinal canal is usually detected during surgical repair of hernia $[3,14]$. Less than $7 \%$ of the cases are diagnosed preoperatively, and $16 \%$ of them in the postoperative period due to postoperative complications [6]. Risk of bladder injury due to intraoperatively detected inguinal bladder herniation was reported in $12 \%$ of the cases $[3,6$, $15,16]$. In our case, luckily, non-contrast CT was performed by emergency physicians to clarify acute renal failure detected in laboratory tests. In this way, preoperative diagnosis was made, and possible complications and surprises were avoided. CT, cystogram, IVU and USG are among the radiological methods that can be used for diagnosis $[2,3]$. CT and cystogram were also used in our case.

After the reduction of the bladder to its anatomical location during the procedure, the repair of the defect with mesh is the routine treatment to prevent recurrence of inguinal herniation $[6,7,14]$. We didn't use mesh to repair the existing defect after the reduction of the bladder because of the deficiency of our equipment. Routine resection of the herniated bladder which is an older practice is only applied in cases such as bladder wall necrosis, the presence of tumor in the herniated tissue and a tight hernial neck $[2,5,6,12,17]$. We didn't make any resection.

In conclusion, inguinal herniation is not a simple entity. Herniation of the bladder into the inguinal canal should come to mind in the presence of risk factors. Before the hernia repair op- eration, at least a simple radiological examination should be requested to prevent undesirable results. It should be kept in mind that there may be voiding difficulties after the procedure and the patient should be monitored with conservative interventions.

Ethics Committee Approval: N / A.

Informed Consent: An informed consent was obtained from the patient.

Publication: The results of the study were not published in full or in part in form of abstracts.

Peer-review: Externally peer-reviewed.

Authorship Contributions: There is not any contributions who may not be listed as authors. Concept - M.C., M.E.P., C.S., B.B.K.; Design - M.C., M.E.P., C.S., B.B.K.; Supervision M.C., M.E.P., C.S., B.B.K.; Resources - M.C., M.E.P., C.S., B.B.K.; Materials - M.C., M.E.P., C.S., B.B.K.; Data Collection and/or Processing - M.C., M.E.P., C.S., B.B.K.; Analysis and/or Interpretation - M.C., M.E.P., C.S., B.B.K.; Literature Search - M.C., M.E.P., C.S., B.B.K.; Writing - M.C., M.E.P., C.S., B.B.K.; Critical Review - M.C., M.E.P., C.S., B.B.K.

Conflict of Interest: The authors declare that they have no conflict of interest.

Financial Disclosure: The authors have declared that they did not receive any financial support for the realization of this study.

\section{References}

[1] Levine B. Scrotal cystocele. J Am Med Assoc 1951;147:1439-41.

https://doi.org/10.1001/jama.1951.73670320003013a

[2] Gonzalez-Urquijo M, Mayagoitia-Gonzalez JC, RodarteShade M, Bermea-Mendoza JH, Gil-Galindo G. Large inguinal bladder hernias: can a preoperative diagnosis be made? Hernia 2019;23:1221-7. https://doi.org/10.1007/s10029-019-01955-3.

[3] Oruç MT, Akbulut Z, Ozozan O, Coşkun F. Urological findings in inguinal hernias: a case report and review of the literature. Hernia 2004;8:76-9.

https://doi.org/10.1007/s10029-003-0157-6

[4] Schewe J, Brands EH, Pannek J. The inguinal bladder diverticulum: a rare differential diagnosis of hernias. Int Urol Nephrol 2000;32:255-6.

https://doi.org/10.1023/a:1007110429906

[5] Pasquale MD, Shabahang M, Evans SR. Obstructive uropathy secondary to massive inguinoscrotal bladder herniation. J Urol 1993;150:1906-8. https://doi.org/10.1016/s0022-5347(17)35931-1

[6] Kraft KH, Sweeney S, Fink AS, Ritenour CWM, Issa MM. Inguinoscrotal bladder hernias: report of a series and review of the literature. Can Urol Assoc J 2008;2:619-23. https://doi.org/10.5489/cuaj.980.

[7] Bisharat M, O'Donnell ME, Thompson T, MacKenzie N, Kirkpatrick D, Spence RA, et al. Complications of inguinoscrotal bladder hernias: a case series. Hernia 2009;13:81-4.

https://doi.org/10.1007/s10029-008-0389-6. 
[8] Gomella LG, Spires SM, Burton JM, Ram MD, Flanigan RC. The surgical implications of herniation of the urinary bladder. Arch Surg 1985;120:964-7. https://doi.org/10.1001/archsurg.1985.01390320084018.

[9] Aras B, Zeren S, Ucar B, Şanal B, Bayhan Z, Korkmaz $\mathrm{M}$, et al. Massive inguinoscrotal bladder hernia causing hydronephrosis: Two cases. Int J Surg Case Rep 2015;16. https://doi.org/10.1016/j.ijscr.2015.05.014.

[10] Papadimitriou SH, Chlepas MA, Kokinacos CP, Papadopoulos CB. Massive Scrotal Cystocele with Bladder Cancer. Br J Urol 1991;67:330-1. https://doi.org/10.1111/j.1464-410x.1991.tb15151.x.

[11] Habib A. A Rare Case of Inguinal Hernia with Complete Bladder Herniation. Case Rep Surg 2017;2017:4658169. https://doi.org/10.1155/2017/4658169.

[12] Moufid K, Touiti D, Mohamed L. Inguinal bladder hernia: four case analyses. Rev Urol 2013;15:32-6. https://www.ncbi.nlm.nih.gov/pmc/articles/PMC3651540/

[13] Won ACM, Testa G. Chronic obstructive uropathy due to uretero-inguinal hernia: A case report. Int J Surg Case Rep 2012;3:379-81. https://doi.org/10.1016/j.ijscr.2012.04.004.

[14] Papatheofani V, Beaumont K, Nuessler NC. Inguinal hernia with complete urinary bladder herniation: a case report and review of the literature. J Surg Case Rep 2020;2020:rjz321. https://doi.org/10.1093/jscr/rjz321.

[15] Catalano O. US evaluation of inguinoscrotal bladder hernias: Report of three cases. Clinical Imaging 1997;21:126-8.

https://doi.org/10.1016/s0899-7071(96)00018-6.

[16] Karaman ZC, Saray A, Dorak C, Tamac NI. Ultrasonographic diagnosis of massive bladder hernia. J Clin Ultrasound 1993;21:534-6. https://doi.org/10.1002/jcu.1870210812.

[17] Wagner AA, Arcand P, Bamberger MH. Acute renal failure resulting from huge inguinal bladder hernia. Urology 2004;64:156-7.

https://doi.org/10.1016/j.urology.2004.03.040. 